\title{
UWAGI NA TEMAT ORGANIZACJI POWSZECHNEGO GŁOSOWANIA KORESPONDENCY JNEGO W CZASIE TRWANIA STANU EPIDEMII
}

\author{
Marcin Strzymiński \\ Uniwersytet w Białymstoku \\ Wydział Prawa \\ ORCID ID: https://orcid.org/0000-0002-7450-8929 \\ e-mail: strzymin@gmail.com
}

\begin{abstract}
Streszczenie: Wybory prezydenckie zaplanowane pierwotnie na 10 maja 2020 roku zbiegły się w czasie z wybuchem epidemii koronawirusa i wprowadzeniem stanu epidemii. W związku z tym polskie państwo musiało podjąć działania, które umożliwią wszystkim obywatelom skorzystanie z przyznanego im przez Konstytucję RP czynnego prawa wyborczego jednocześnie zapewniając im bezpieczeństwo w wymiarze zdrowotnym. Rozwiązaniem tego problemu miało być powszechne głosowanie wyłącznie w formie korespondencyjnej. Celem artykułu jest zebranie i omówienie najważniejszych wątpliwości związanych z organizacją takiej formy wyborów, w tym między innymi kwestii: zapewnienia tajności głosowania, organu odpowiedzialnego za przeprowadzenie wyborów, zmian w prawie wyborczym w okresie krótszym niż 6 miesięcy przed datą głosowania, a także możliwości przeprowadzenia wyborów w czasie stanu nadzwyczajnego.
\end{abstract}

Słowa kluczowe: głosowanie korespondencyjne, wybory, stan epidemii, wybory prezydenckie, Polska, kodeks wyborczy

\section{WPROWADZENIE. SYTUACJA PRAWNO-POLITYCZNA POLSKI PRZED WYBORAMI PREZYDENCKIMI W 2020 ROKU.}

Głosowanie korespondencyjne jest jednym z alternatywnych sposobów głosowania ${ }^{1}$ od wielu lat uznawanym przez doktrynę prawa konstytucyjnego i stanowi część systemów wyborczych wielu krajów demokratycznych ${ }^{2}$. Polega ono na tym, że wyborca wyraża wolę oddania głosu w ten właśnie sposób, otrzymuje

1 Sokala Andrzej, Michalak Bartłomiej, Uziębło Piotr, Leksykon prawa wyborczego i referendalnego oraz systemów wyborczych, Warszawa 2013, s. 19.

2 Banaszak Bogusław, Kodeks wyborczy. Komentarz, Warszawa 2015, s. 129. 
materiały do głosowania pocztą, a następnie w tej samej drodze odsyła wypełnioną kartę do głosowania na wskazany w przepisach adres ${ }^{3}$. Głosowanie korespondencyjne pojawiło się po raz pierwszy w Kodeksie wyborczym z 5 stycznia 2011 roku. Zgodnie z art. 38 § 2 głosowanie korespondencyjne było głosowaniem osobistym i dotyczyło wyłącznie głosowania w obwodach utworzonych za granicą. Wyborca mógł zgłosić zamiar oddania w ten sposób głosu właściwemu terytorialnie konsulowi do 15 dnia przed dniem wyborów. Kilka miesięcy później, w maju 2011 roku, po nowelizacji kodeksu wyborczego ${ }^{4}$ rozszerzono krąg wyborców, którzy mogli głosować korespondencyjnie - w ten sposób z czynnego prawa wyborczego mogły skorzystać także osoby niepełnosprawne o znacznym lub umiarkowanym stopniu niepełnosprawności. Taki zamiar należało zgłosić do 21 dnia przed dniem wyborów. Bardzo istotna była nowelizacja ustawy z lipca 2014 roku $^{5}$, która rozszerzyła możliwość głosowania korespondencyjnego na wszystkich wyborców. W opinii prawnej przygotowanej przez Krzysztofa Skotnickiego ${ }^{6}$ jej autor generalnie pozytywnie wyrażał się o takiej możliwości, zwracając jednak uwagę, że może ona zwłaszcza w przypadku wyborów samorządowych przyczynić się do oszustw wyborczych. W styczniu 2018 roku dokonano kolejnych zmian w kodeksie wyborczym. Ustawą o zmianie niektórych ustaw w celu zwiększenia udziału obywateli w procesie wybierania, funkcjonowania i kontrolowania niektórych organów publicznych ograniczono możliwość do głosowania korespondencyjnego wyłącznie do osób niepełnosprawnych ${ }^{7}$.

6 sierpnia 2020 roku upływała kadencja Prezydenta Rzeczypospolitej Polskiej i zgodnie z art. 128 ust. 2 Konstytucji RP Marszałek Sejmu był zobligowany do zarządzenia wyborów Prezydenta RP na dzień przypadający nie wcześniej niż na 100 dni i nie później niż na 75 dni przed upływem kadencji urzędującego prezydenta. Ustawa o wyborze Prezydenta Rzeczypospolitej Polskiej precyzuje, że wybory mogą zostać wyznaczone na dzień wolny od pracy. Wypełniając ten obowiązek 5 lutego 2020 roku Marszałek Sejmu zarządziła wybory prezydenckie i wyznaczyła je na 10 maja 2020 roku. Jednak w związku z wprowadzeniem 20 marca 2020 roku stanu epidemii na obszarze całego terytorium Rzeczypospolitej Polskiej powstał istotny problem: w jaki sposób zapewnić bezpieczne głosowanie $\mathrm{w}$ wyborach prezydenckich. $\mathrm{W}$ dniu ogłoszenia epidemii w kwarantannie przebywało ok. 41 tys. osób ${ }^{8}$ i należało się spodziewać, że ta liczba będzie stale rosnąć. W związku z tym spora grupa wyborców podlegała tzw. absencji przymusowej, gdy wyborca chce zagłosować, ale z przyczyn obiektywnych nie może

\footnotetext{
3 Sokala A., op. cit., s. 67.

4 Dz.U. $2011 \mathrm{nr} 147$ poz. 881.

5 Dz.U. 2014 poz. 1072.
}

6 Opinia prawna na temat poselskiego projektu ustawy o zmianie ustawy - Kodeks wyborczy oraz niektórych innych ustaw (druk nr 1786) (http://orka.sejm.gov.pl/rexdomk7.nsf/Opdodr?OpenPage\&nr=1786 (dostęp: 18 marca 2021 roku)

7 Dz.U. 2018 poz. 130.

8 https://koronawirus-w-polsce.pl/ (dostęp 18 marca 2021 roku). 


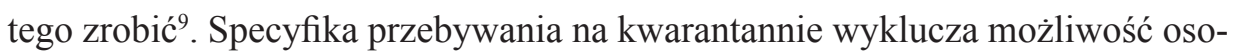
bistego oddania głosu w lokalu wyborczym, a należało zapewnić takim osobom możliwość skorzystania z prawa wyborczego. Ustawodawca zdając sobie sprawę $\mathrm{z}$ ograniczeń jakie niesie epidemia w ustawie o zmianie ustawy o szczególnych rozwiązaniach związanych z zapobieganiem, przeciwdziałaniem i zwalczaniem COVID-19, innych chorób zakaźnych oraz wywołanych nimi sytuacji kryzysowych oraz niektórych innych ustaw z 31 marca 2020 roku $^{10}$ wprowadził możliwość głosowania korespondencyjnego dla osób podlegających w dniu głosowania obowiązkowej kwarantannie, izolacji lub izolacji w warunkach domowych, oraz osobom, które najpóźniej w dniu głosowania kończyły 60 lat. Zamiar głosowania korespondencyjnego wyborca powinien zgłosić komisarzowi wyborczemu do 15 dnia przed dniem wyborów, z wyjątkiem wyborcy podlegającego w dniu głosowania obowiązkowej kwarantannie, izolacji lub izolacji w warunkach domowych, który zamiar głosowania komisarzowi wyborczemu zgłasza do 5 dnia przed dniem wyborów.

6 kwietnia 2020 roku Klub Parlamentarny Prawo i Sprawiedliwość złożył w Sejmie poselski projekt ustawy o szczególnych zasadach przeprowadzania wyborów powszechnych na Prezydenta Rzeczypospolitej Polskiej zarządzonych w 2020 roku. Warto podkreślić, że projektodawcy dopuszczali możliwość zmiany terminu wyborów nie wskazując w tytule proponowanej ustawy konkretnej daty. Artykuły 1 i 2 ustawy zawierały normę o charakterze blankietowym, co nadawało jej charakter wybitnie ekstraordynaryjny. Epizodyczność tej ustawy wyrażała się również w fakcie, że w 2018 roku zniesiono możliwość skorzystania z oddania głosu korespondencyjnie przez wszystkich wyborców. Przywracano ją de facto na przeprowadzenie tych konkretnych wyborów prezydenckich. Pakiety wyborcze miały zostać dostarczone bez potrzeby zgłaszania wniosku o skorzystanie z możliwości głosowania korespondencyjnego przez wskazanego w ustawie operatora pocztowego od 7 dni do dnia przypadającego przed dniem głosowania.

Pierwszym celem badawczym niniejszego artykułu jest wykazanie, że choć organy władzy publicznej były uprawnione do nowelizacji prawa wyborczego to jednak sposób przeprowadzenia procesu legislacyjnego i zaproponowane zmiany były niezasadne i w skrajnym przypadku mogły całkowicie uniemożliwić przeprowadzenie wyborów prezydenckich. Kolejnym celem badawczym była ocena wpływu zaproponowanych zmian na czynne prawo wyborcze m.in. poprzez wprowadzenie swego rodzaju przymusu wyborczego. Dalej krytyce poddane zostało przede wszystkim ograniczenie roli Państwowej Komisji Wyborczej w procesie organizacji wyborów oraz przejęcie większości jej zadań przez organy władzy wykonawczej. Jednocześnie zbadano i negatywnie zweryfikowano zarzuty o naruszeniu zasady tajności głosowania oraz tzw. ciszy legislacyjnej. Ostatnim celem

9 Korycki Krzysztof, Alternatywne techniki głosowania a frekwencja wyborcza, Studia Wyborcze, Tom XXIII, 2017, s. 84.

${ }^{10}$ Dz.U. 2020 poz. 568. 
niniejszego artykułu jest znalezienie odpowiedzi na pytanie, czy istniała potrzeba i przesłanki wprowadzenia stanu nadzwyczajnego jako sposobu zaradczego na problemy z organizacją wyborów prezydenckich w 2020 roku.

W ramach niniejszego artykułu posłużono się przede wszystkim metodą dogmatyczno-prawną oraz w mniejszym zakresie opisową i socjologiczną. Dokonano analizy przepisów między innymi kodeksu wyborczego i ustawy o szczególnych zasadach przeprowadzania wyborów powszechnych na Prezydenta Rzeczypospolitej Polskiej zarządzonych w 2020 r., a także orzecznictwa Trybunału Konstytucyjnego.

\section{CISZA LEGISLACYJNA}

W 2020 roku część polityków, przedstawicieli doktryny, a także Rzecznik Praw Obywatelskich krytycznie odnosili się do zmian kodeksu wyborczego dotyczących możliwości głosowania wyłącznie w formie korespondencyjnej zarzucając im między innymi łamanie ciszy legislacyjnej. Sąd Najwyższy w opinii przygotowanej dla Senatu ${ }^{11}$ podkreślił, że Sejm wbrew dyrektywom wynikającym z orzecznictwa Trybunału Konstytucyjnego nie zachował minimalnego okresu ciszy legislacyjnej w zakresie istotnych zmian prawa wyborczego, który wynosi 6 miesięcy przed wyborami rozumianymi jako ogół czynności ujętych w kalendarzu wyborczym. Sąd Najwyższy nie rozwinął tego zarzutu, a należy zauważyć, że ów zakaz zmian w prawie wyborczym nie ma charakteru bezwzględnego jest jedynie pewnym standardem, dyrektywą, które należałoby zachowywać dla spełnienia zasady demokratycznego państwa prawnego. Trybunał Konstytucyjny w swoim orzeczeniu z 20 lipca 2011 roku $^{12}$ podkreślił bowiem, że mogą zaistnieć wyjątki od sześciomiesięcznego okresu ciszy legislacyjnej, które wynikałyby z nadzwyczajnych okoliczności o charakterze obiektywnym. Należy w tym miejscu przypomnieć, że nowelizacje kodeksu wyborczego dotyczące głosowania korespondencyjnego z maja 2011 roku oraz lipca 2014 roku zostały dokonane w czasie krótszym niż postulowane pół roku przed wyborami. Cisza legislacyjna powinna dotyczyć istotnych zmian w prawie wyborczym. Kodeks Dobrej Praktyki w Sprawach Wyborczych przyjęty przez Komisję Wenecką zalicza do nich: właściwy system wyborczy, członkostwo komisji wyborczych oraz ustalanie granic okręgów wyborczych ${ }^{13}$, a polski Trybunał Konstytucyjny jako istotne zmiany

${ }^{11}$ Opinia $w$ przedmiocie ustawy z dnia 6 kwietnia 2020 r. o szczególnych zasadach przeprowadzania wyborów powszechnych na Prezydenta Rzeczypospolitej Polskiej zarzadzonych w 2020 r. (druk senacki nr 99) http://www.sn.pl/aktualnosci/SitePages/Wydarzenia.aspx?ItemSI$\mathrm{D}=630-0 \mathrm{dc} 69815-3 a d e-42 \mathrm{fa}-\mathrm{bbb} 8-549 \mathrm{c} 3 \mathrm{c} 6969 \mathrm{c} 5 \&$ ListName=Wydarzenia (dostęp: 11 marca 2021 roku).

12 Wyrok Trybunału Konstytucyjnego z 20 lipca 2011 roku, sygn.. K 9/11.

${ }_{13}$ Kodeks Dobrej Praktyki w Sprawach Wyborczych https://bisnetus.files.wordpress.com/2016/03/ kodeks_dobrej_praktyki_w_sprawach_wyborczych.pdf(dostęp 12 kwietnia 2021 roku). 
wymienia: wielkość okręgów wyborczych, wysokość progów wyborczych oraz przyjęty system ustalania wyników wyborów ${ }^{14}$. Sposobu głosowania, który ściśle rzecz ujmując jest czynnością techniczną zgodnie z przyjętym orzecznictwem i wytycznymi międzynarodowych instytucji nie sposób zaliczyć do zmian istotnych, choć prima facie takim może się wydawać. Wydaje się, że w przypadku stanu epidemii zachodziły ekstraordynaryjne, obiektywne okoliczności, które wymagały podjęcia pilnych zmian w prawie wyborczym, które umożliwiłyby, a przynajmniej znacznie ułatwiły wyborcom skorzystanie z czynnego prawa wyborczego. Bezwzględny zakaz zmian w ordynacji wyborczej jest przewidziany przez Konstytucję tylko w czasie stanu nadzwyczajnego oraz 90-dniowym okresie po jego zakończeniu. Senat, który de facto stosując obstrukcję parlamentarną wykorzystał maksymalny, 30-dniowy czas na podjęcie decyzji odnośnie ustawy uchwalonej przez Sejm przyczynił się do tego, że ustawa weszła w życie tuż przed dniem głosowania. Jak zwracają uwagę przedstawiciele doktryny, nawet czternastodniowe vacatio legis nie zawsze jest w stanie zabezpieczyć stabilność prawa wyborczego ${ }^{15}$, a w przypadku ustawy z 6 kwietnia 2020 roku vacatio legis praktycznie nie istniało, ponieważ ustawa wchodziła w życie z dniem następującym po dniu ogłoszenia, zaledwie na dzień przed planowaną pierwszą turą wyborów prezydenckich zarządzonych na 10 maja 2020 roku. Okres ten należy uznać za zbyt krótki i naruszający zasadę zaufania obywateli do państwa oraz pewności prawa.

\section{PRZYMUS WYBORCZY}

Przymus wyborczy jest mechanizmem stosowanym w wielu krajach na świecie (m.in. Australii, Argentynie, Belgii, Włoszech), który polega na obowiązku wzięcia udziału w wyborach przez osoby uprawnione do głosowania. Charakteryzuje się on przede wszystkim zastosowaniem sankcji wobec wyborcy, który nie wypełnił obowiązku wyborczego, co w założeniu ma mobilizować do aktywności wyborczej $^{16}$. W wielu krajach z obowiązku tego wyłączone są jednak określone kategorie osób, które dysponują czynnym prawem wyborczym ${ }^{17}$. Artykuł 2 ust. 4 ustawy z 6 kwietnia 2020 roku przewidywał, że wyborcy nie składają wniosku o skorzystanie z możliwości głosowania korespondencyjnego, a pakiety wyborcze zostaną dostarczone do oddawczych skrzynek pocztowych wyborców. W związku z tym można zastanowić się, czy takie rozwiązanie nie stanowi zawoalowanej formy przymusu wyborczego rozpatrywanego w dwóch aspektach. Po pierwsze, wyborca

${ }^{14}$ Wyrok Trybunału Konstytucyjnego z 3 listopada 2006 roku, sygn. akt K 31/06.

15 Jakubowski Pawel, Cisza legislacyjna - zasada prawa wyborczego w Rzeczypospolitej Polskiej, Przegląd Sejmowy 4(129)/2015, s. 13.

${ }^{16}$ Kryszeń Grzegorz, Standardy prawne wolnych wyborów parlamentarnych, Białystok 2007, s. 243.

17 ibidem. 
otrzymując pakiet wyborczy nie może w pełni nieskrępowany sposób podjąć decyzji o rezygnacji z głosowania. Wyborcy, którzy w normalnych warunkach zapewne nie wzięliby udziału w wyborach mogą odczuwać presję ze strony organów państwa, by skorzystać z możliwości oddania głosu dysponując kartą do głosowania. Bez dokonania racjonalnej oceny sytuacji i na przykład podstawowej wiedzy na temat programu wyborczego kandydatów na urząd Prezydenta RP, działając pod wpływem impulsu (wypełniając kartę do głosowania jeszcze w trakcie formalnie trwającej kampanii wyborczej) lub swojego otoczenia w sposób nie do końca świadomy mogą wpłynąć na wynik wyborczy, zniekształcając faktyczne poparcie dla poszczególnych kandydatów. Po drugie pewna forma przymusu wyborczego mogła zaistnieć w związku z brakiem regulacji dotyczących zwrotu niewypełnionych kart do głosowania. Zgodnie z przepisami karnymi zawartymi w ustawie z 6 kwietnia 2020 roku karze grzywny podlega ten, kto bez uprawnienia niszczy pakiet wyborczy. Nieskorzystanie z pakietu wyborczego mogłoby prowadzić do ich masowego niszczenia przez wyborców. Brak adnotacji w spisie wyborczym o oddaniu głosu rodziłoby odpowiedzialność karną w stosunku do setek tysięcy, a może nawet milionów ludzi. W ten sposób spełniona zostałaby przesłanka charakterystyczna dla przymusu wyborczego, czyli zastosowanie sankcji wobec osób niebiorących udziału w głosowaniu.

\section{CZYNNE PRAWO WYBORCZE I TAJNOŚĆ GŁOSOWANIA}

Podstawowym sposobem głosowania jest oddanie głosu w lokalu wyborczym ${ }^{18}$. Takie samo stanowisko zajęła między innymi Komisja Wenecka w Kodeksie Dobrych Praktyk Wyborczych, stwierdzając że „Wyborcy muszą mieć zawsze możliwość oddania głosu w lokalu wyborczym; inne metody głosowania są dopuszczalne jednak pod pewnymi warunkami" ${ }^{19}$. Powszechne głosowanie korespondencyjne (all -postal voting) jako jedyny sposób oddania głosu jest na świecie stosowany bardzo rzadko i występuje obecnie między innymi w kilku stanach USA. Takie rozwiązanie w Polsce zostało przyjęte po raz pierwszy w historii w ustawie z 6 kwietnia 2020 roku. Z kilku powodów mogło naruszać jednak gwarantowane konstytucją czynne prawo wyborcze. Po pierwsze, pakiety wyborcze miały być wysyłane na adres zamieszkania wyborcy ujętego w spisie wyborczym. Zgodnie z art. 3 ust. 1 ustawy z 6 kwietnia 2020 roku wyznaczony operator (w tym wypadku Poczta Polska) „zapewnia w przypadku głosowania w kraju, w terminie przypadającym od 7 dni do dnia przypadającego przed dniem głosowania, doręczenie pakietu wyborczego bezpośrednio do oddawczej skrzynki pocztowej wyborcy lub pod adres wyborcy wskazany w części A spisu wyborców". Z uwagi na fakt, że wielu wyborców nie

${ }^{18}$ Zbieranek Jarosław, Alternatywne metody glosowania w polskim prawie wyborczym, Warszawa 2013, s. 13-14.

19 Kodeks dobrej praktyki..., op. cit. 
mieszka pod adresem ujętym w spisie, to pakiety mogłyby faktycznie nie trafić do rąk adresatów i uniemożliwić im tym samym oddanie głosu. Po drugie, wprawdzie wyborca mógł dopisać się do spisu na wniosek wniesiony do urzędu gminy najpóźniej w dniu wejścia w życie ustawy, ale ograniczone możliwości techniczne i logistyczne, a także pośpiech w przygotowaniu całego przedsięwzięcia kazały przypuszczać, że dojdzie do wielu sytuacji, w których pakiety wyborcze nie trafią na czas do rąk wyborców, nawet gdyby udało im się dopisać do spisu wyborców. Osoby, które chciałyby skorzystać z takiej możliwości mogłyby nie być pewne kiedy taki termin upłynie, zwłaszcza gdyby termin wyborów uległ przesunięciu. Ustawa, co zrozumiałe, likwidowała też możliwość oddania głosu na podstawie zaświadczenia o prawie glosowania poza miejscem zamieszkania.

Po trzecie, według ustawy z 6 kwietnia 2020 roku do postępowania z pakietami wyborczymi nieodebranymi przez wyborców o których mowa w ust. 2 pkt 1 i 2 oraz do postępowania z kopertami zwrotnymi odebranymi od tych wyborców stosuje się kodeks wyborczy. Ponieważ pakiety wyborcze miały być wrzucane do skrzynek oddawczych ${ }^{20}$ jako przesyłki nierejestrowane (niepolecone, których odbioru kwitować nie trzeba) zatem pojęcie „nieodebranego" pakietu wyborczego w istocie byłoby fikcyjne. Dotychczas pakiety wyborcze były traktowane jako rejestrowana przesyłka polecona, której odbiór musiał zostać pokwitowany przez wyborcę. Z uwagi na fakt, że pakiet wyborczy był zwykłą przesyłką bezadresową, którą można potraktować jak ulotkę istniało poważne ryzyko, że nie trafią one do wyborcy, zostaną zagubione, bądź zostaną popełnione inne błędy przy doręczeniu np. wrzucenie kilku pakietów do jednej skrzynki oddawczej, omyłkowe pominięcie skrzynki itp.

Wątpliwości części środowisk i przedstawicieli doktryny budziła kwestia tajności głosowania. Podnoszono, że „sposób głosowania każdego wyborcy będzie możliwy do ustalenia, gdyż do karty wyborczej dołączone będą jego dane identyfikacyjne"21. Tymczasem w tej sprawie w 2011 roku wypowiedział się Trybunał Konstytucyjny, który uznał, że sposób, w którym następuje separacja karty do głosowania od oświadczenia wyborcy poprzez wykorzystanie dwóch kopert, tożsama ze sposobem głosowania w wyborach korespondencyjnych, które miały odbyć się 10 maja nie narusza zasady tajności głosowania. Według TK „taki sposób uregulowania procedury oddania głosu poza lokalem wyborczym nie narusza zasady tajności głosowania, gdyż ustawodawca wskazał podmioty odpowiedzialne za realizację tej zasady na poszczególnych etapach procesu wyborczego i stworzył rozbudowany, opisany wyżej mechanizm gwarantujący, że treść decyzji konkretnego wyborcy nie będzie znana osobom postronnym"22.

${ }^{20} \mathrm{https}: / /$ www.poczta-polska.pl/glosowanie-korespondencyjne-w-kraju/ (dostęp 14 kwietnia 2021 roku).

${ }^{21} \mathrm{https}$ //prawo.gazetaprawna.pl/artykuly/1472940,wykladowcy-prawa-apel-wybory-prezydenckie-konstytucja-glosowanie-korespondencyjne.html (dostęp 20 kwietnia 2021 roku).

${ }^{22}$ Wyrok Trybunału Konstytucyjnego z 20 lipca 2011 roku, sygn.. K 9/11. 


\section{ROLA WŁADZY WYKONAWCZEJ I PKW W ORGANIZACJI GŁOSOWANIA KORESPONDENCYJNEGO}

Zgodnie z kodeksem wyborczym Państwowa Komisja Wyborcza jest stałym najwyższym organem wyborczym właściwym w sprawach przeprowadzania wyborów i referendów. Do jej głównych zadań należy sprawowanie nadzoru nad przestrzeganiem prawa wyborczego, prowadzenie rejestru wyborców, sporządzanie spisu wyborców oraz ustalanie wzorów urzędowych formularzy, druków wyborczych i pieczęci organów wyborczych. Ustawa z 6 kwietnia 2020 roku redukowała rolę PKW w organizacji wyborów do minimum, a organizacja i przeprowadzenie wyborów korespondencyjnych zostały niemal całkowicie powierzone egzekutywie. Według ustawy z 16 kwietnia 2020 r. o szczególnych instrumentach wsparcia w związku z rozprzestrzenianiem się wirusa SARS-CoV-2 w okresie obowiązywania stanu zagrożenia epidemicznego albo stanu epidemii przy przeprowadzaniu wyborów powszechnych na Prezydenta Rzeczypospolitej Polskiej zarządzonych w 2020 r. nie stosuje się przepisów kodeksu wyborczego dotyczących m.in. wydawania zaświadczeń o prawie do głosowania, przekazywania informacji o terminie wyborów, godzinach głosowania i sposobie głosowania w formie ulotek, a także ustalania przez Państwową Komisję Wyborczą wzoru karty do głosowania i zarządzania przez nią druku tych kart. Tym samym zastrzeżone do tej pory dla najwyższego organu wyborczego kompetencje przejmował minister właściwy do spraw aktywów państwowych, który co należy podkreślić, jedynie po zasięgnięciu opinii PKW (która nie miała charakteru wiążącego) określał w drodze rozporządzenia m.in. wzór karty do głosowania, w tym sposób oznaczenia jej autentyczności, wzór i rozmiar koperty na pakiet wyborczy, koperty zwrotnej i koperty na kartę do głosowania. Ponadto zlecał on sporządzanie pakietów wyborczych przez wskazany przez niego podmiot lub podmioty. Zgodnie z art. 3 ust. 4 ustawy z 6 kwietnia 2020 roku minister aktywów państwowych mógł określić w drodze rozporządzenia dodatkowe elementy wchodzące w skład pakietu wyborczego, mając na względzie zapewnienie wyborcom, skutecznego prawa do głosowania. Trudno powiedzieć o jakie elementy dodatkowe mogło chodzić ustawodawcy (być może chodziło np. o nakładki brajlowskie dla wyborców niewidomych), ale pewien niepokój mogła wzbudzać sama kompetencja do arbitralnego i samodzielnego ustalania składu pakietu wyborczego. Do nowych kompetencji ministra ds. aktywów państwowych należało też określenie postępowania z kopertami zwrotnymi. Pochłaniał on też kompetencje innych organów, w tym ministra właściwego ds. łączności (np. określenie szczegółowego trybu doręczania do wyborcy pakietów wyborczych przez operatora wyznaczonego) oraz komisji wyborczych (sporządzanie pakietów wyborczych). Intencją ustawodawcy, który powierzał organizację wyborów właśnie ministrowi aktywów państwowych było zapewne to, aby cały proces wyborczy przebieg szybko i sprawnie, ze względu na fakt, że Poczta Polska jako „wyznaczony operator” była spółką Skarbu Państwa objętą nadzorem właścicielskim Ministerstwa Aktywów 
Państwowych. Jednak w efekcie PKW została sprowadzona do roli biernego obserwatora wyborów korespondencyjnych, a minister aktywów państwowych stał się ,wyborczym dyktatorem”. Przejmował on de facto jednoosobowy zarząd nad procedurą organizacji wyborów, pozostawiając w zasadzie PKW tylko prawo do ogłoszenia wyników wyborów. 7 maja 2020 roku Państwowa Komisja Wyborcza poinformowała, że ze względu na obowiązujące regulacje prawne PKW została pozbawiona instrumentów koniecznych do wykonywania obowiązków wybory 10 maja nie mogą się odbyć23.

Oczywiście istnieją modele administracji wyborczej, w których to rząd pod nadzorem niezależnego organu pełni rolę organizacyjną i techniczną. Na przykład we Francji organizacją procesu wyborczego zajmuje się minister spraw wewnętrznych $^{24}$. Reformę administracji wyborczej w Polsce, która włącza w cały proces administrację rządową warto podnieść jako postulat de lege ferenda i przedyskutować go w debacie publicznej, ale zmiany wprowadzone w ustawie z 6 kwietnia 2020 roku, które poszczególne etapy procesu wyborczego odbierały PKW i oddawały w ręce przedstawiciela egzekutywy należy ocenić negatywnie.

\section{STAN NADZWYCZAJNY A WYBORY}

$\mathrm{Na}$ koniec należy poczynić jeszcze jedną istotną uwagę nie odnoszącą się stricte do głosowania korespondencyjnego, ale wyborów prezydenckich w 2020 roku w całości. Rzecznik Praw Obywatelskich wielokrotnie podnosił, że nie można przeprowadzić wyborów prezydenckich w jakiejkolwiek formie ze względu na fakt, że w Polsce faktycznie trwał stan nadzwyczajny. Taki pogląd należy zdecydowanie odrzucić. W Polsce stan nadzwyczajny może wprowadzić prezydent na wniosek Rady Ministrów (stan wojenny i stan wyjątkowy) i Rada Ministrów (stan klęski żywiołowej). Żaden z tych reżimów nie został de iure wprowadzony. W związku z tym nie zaistniała przesłanka uprawniająca do zakazu przeprowadzania wyborów. Pojęcie faktycznego stanu nadzwyczajnego, którym posługiwał się RPO jest jedynie terminem teoretycznym, który może być rozpatrywany wyłącznie w dyskusjach przedstawicieli doktryny. Skoro organy władzy wykonawczej nie zdecydowały się wprowadzić stanu nadzwyczajnego, najwidoczniej uznały, że nie ma ku temu podstaw. W przypadku wprowadzenia ekstraordynaryjnego reżimu jedną z jego istotnych cech jest dyskrecjonalność. Wydaje się, że na przełomie marca i kwietnia 2020 roku nie zachodziły przesłanki do wprowadzenia stanu nadzwyczajnego tzn. sytuacja związana $\mathrm{z}$ epidemią koronawirusa nie była sytuacją szczególnego zagrożenia, konstytucyjne środki były wystarczające do

${ }^{23} \mathrm{https} / / /$ pkw.gov.pl/aktualnosci/wyjasnienia-stanowiska-komunikaty/komunikat-panstwowej-komisji-wyborczej-z-dnia-7-maja-2020-roku (dostęp 24 kwietnia 2021 roku).

${ }^{24}$ Sześciło Dawid, Modele administracji wyborczej w wybranych państwach, Studia Wyborcze 2013, tom 15 . 
walki z nią. Jak podkreśla Krzysztof Prokop przez zwykłe środki konstytucyjne należy rozumieć „wszystkie nomy prawne, dające się skonstruować na podstawie przepisów konstytucyjnych spoza rozdziału XI oraz odpowiednich ustaw"25. Należy pamiętać, że wprowadzenie stanu nadzwyczajnego bez uzasadnienia mogłoby stanowić naruszenie konstytucji i rodzić odpowiedzialność konstytucyjną odpowiednich organów. Zakładając, że 6 kwietnia 2020 roku zostałby wprowadzony stan wyjątkowy na 90 dni, a następnie przedłużony o kolejne 60 dni, to biorąc pod uwagę zakaz przeprowadzania wyborów w okresie 90 dni po zakończeniu stanu nadzwyczajnego wybory prezydenckie mogłyby odbyć się najwcześniej na początku grudnia 2020 roku. Biorąc pod uwagę, że liczba zachorowań w grudniu była bardzo wysoka mogłoby to przeprowadzenie wyborów mogłoby okazać się niemożliwe. Jedynym skutecznym rozwiązaniem byłoby wprowadzenie wówczas po raz kolejny stanu nadzwyczajnego, zanim upłynie 90-dniowy okres, w którym obowiązywałby zakaz przeprowadzania wyborów. Inaczej groziłoby to utratą mandatu do wykonywania funkcji przez prezydenta. Konstytucja RP w art. 228 ust. 7 wskazuje bowiem, że kadencje organów ulegają odpowiedniemu przedłużeniu. W ówczesnej sytuacji epidemicznej nie można było traktować potencjalnej niemożności przeprowadzenia wyborów jako jedynej lub głównej przesłanki wprowadzenia stanu nadzwyczajnego. Naruszałoby to zasadę celowości i proporcjonalności, gdyż nie odpowiadało to ówczesnemu stopniowi zagrożenia, ani nie zmierzało do szybkiego przywrócenia normalnego funkcjonowania państwa. Podobne stanowisko zajął Sąd Najwyższy w uzasadnieniu uchwały z 3 sierpnia 2020 roku, w której stwierdził ważność wyborów prezydenckich stanowiąc, że: „prawo wyborcze ma służebny charakter, gdyż umożliwia wybór organów przedstawicielskich. Konieczność zapewnienia ciągłości władzy państwowej w oparciu o legitymację demokratyczną musi być priorytetem normatywnym również w sytuacjach wyjątkowych"26.

\section{PODSUMOWANIE}

Zarzuty o łamanie ciszy legislacyjnej oraz naruszenia tajności głosowania podnoszone przez część doktryny należy uznać w tym przypadku za niesłuszne, ponieważ zarówno polski Trybunał Konstytucyjny w swoich orzeczeniach, jak i przygotowany przez Komisję Wenecką Kodeks Dobrej Praktyki w Sprawach Wyborczych dopuszczają możliwość zmian w prawie wyborczym w ważnych przypadkach, a sposobu głosowania nie uznają za zmianę istotną. Podobnie jest

${ }^{25}$ Prokop Krzysztof, Stany nadzwyczajne w Konstytucji RP z 2 kwietnia 1997 roku, Białystok 2005, s. 19-20.

26 Uzasadnienie uchwały Sądu Najwyższego z dnia 3 sierpnia 2020 r. http://www.sn.pl/ aktualnosci/SitePages/Komunikaty_o_sprawach.aspx?ItemSID=389-b6b3e804-2752-4c7d-bcb47586782a1315\&ListName=Komunikaty_o_sprawach (dostęp: 24 kwietnia 2021 roku) 
z zarzutami o zakaz przeprowadzania wyborów w czasie stanu nadzwyczajnego, który de iure nie został wprowadzony. Potencjalne trudności w przeprowadzeniu wyborów nie mogą stanowić jedynego kryterium wprowadzenia reżimu nadzwyczajnego. Niewątpliwie ustawodawca wiedziony obiektywnymi przesłankami, ze względu na panującą epidemię miał prawo dokonać zmian dotyczących sposobu głosowania. Inną sprawą pozostaje jednak zasadność takiego rozwiązania i ryzyko fiaska jego realizacji. Planowane powszechne głosowanie korespondencyjne $\mathrm{w}$ formule przewidzianej w ustawie z 6 kwietnia 2020 roku wprowadziłoby pewną formę przymusu wyborczego - umieszczenie we wszystkich skrzynkach oddawczych pakietów wyborczych mogło na przykład wytworzyć presję na obywatelach, by ci skorzystali z prawa do oddania głosu mimo deklarowanej wcześniej świadomej absencji. Z drugiej strony ze względu na problemy techniczno-organizacyjne mogło dojść do częściowego naruszenia czynnego prawa wyborczego poprzez prawdopodobieństwo niedostarczenia pakietów wyborczych do rąk adresatów (ze względu na ich nierejestrowany charakter) i potencjalnych kłopotów z kopertami zwrotnymi. Krytycznie należy odnieść się też do przekazania kompetencji do organizacji wyborów organom władzy wykonawczej. W Polsce bowiem od wielu lat to Państwowa Komisja Wyborcza jest wyspecjalizowanym organem powołanym do organizacji wyborów i referendów. Ma ona odpowiednie kadry, zaplecze techniczno-organizacyjne i doświadczenie w tej kwestii. Wszelkie odstępstwa od tej zasady naruszają zasadę zaufania obywateli do państwa, oraz powodują chaos prawny, który prowadzi do wystąpienia szeregu problemów np. z przygotowaniem i drukiem pakietów wyborczych. Organy władzy wykonawczej mogą przy organizacji wyborów pełnić jedynie rolę pomocniczą, ale nie wiodącą. Biorąc pod uwagę powyższe rozważania należy uznać, że bardziej racjonalne było przeprowadzenie w pierwszym (majowym terminie) wyborów w formie tradycyjnej z możliwością oddania głosu w drodze korespondencyjnej, jak się zresztą ostatecznie stało na przełomie czerwca i lipca 2020 roku.

Title: Comments on the organisation of the all-postal voting during the state of epidemic

\begin{abstract}
The presidential election originally scheduled for 10 May 2020 coincided with an outbreak of coronavirus and the introduction of an epidemic state. As a result, the Polish state had to take measures which would enable all citizens to exercise their right to vote granted by the Constitution of the Republic of Poland while ensuring their health security. The solution to this problem was to be all-postal voting. The aim of this article is to collect and discuss the most important doubts related to the organisation of such a form of voting, including among others: ensuring the secrecy of the ballot, the authority responsible for holding the election, changes in electoral law in the period less than 6 months before the date of voting, as well as the possibility of holding elections during the state of emergency.
\end{abstract}

Keywords: postal voting, voting, state od epidemic, presidential election, Poland, Electoral Code 


\section{BIBLIOGRAFIA}

1. Banaszak B. (2015) Kodeks wyborczy. Komentarz, Warszawa.

2. Jakubowski P., Cisza legislacyjna - zasada prawa wyborczego w Rzeczypospolitej Polskiej, Przegląd Sejmowy 4(129)/2015.

3. Korycki K., Alternatywne techniki głosowania a frekwencja wyborcza, Studia Wyborcze, Tom XXIII, 2017.

4. Kryszeń G. (2007) Standardy prawne wolnych wyborów parlamentarnych, Białystok.

5. Prokop K. (2005) Stany nadzwyczajne w Konstytucji RP z 2 kwietnia 1997 roku, Białystok.

6. Sokala A., Michalak B., Uziębło P. (2013) Leksykon prawa wyborczego i referendalnego oraz systemów wyborczych, Warszawa.

7. Sześciło D. (2013), Modele administracji wyborczej w wybranych państwach, Studia Wyborcze 2013, tom 15.

8. Zbieranek J., Alternatywne metody głosowania w polskim prawie wyborczym, Warszawa.

Akty prawne

1. Ustawa z dnia 27 maja 2011 r. o zmianie ustawy - Kodeks wyborczy oraz ustawy - Przepisy wprowadzające ustawę - Kodeks wyborczy (Dz.U. 2011 nr 147 poz. 881).

2. Ustawa z dnia 11 lipca 2014 r. o zmianie ustawy - Kodeks wyborczy oraz niektórych innych ustaw (Dz.U. 2014 poz. 1072).

3. Ustawa z dnia 11 stycznia 2018 r. o zmianie niektórych ustaw w celu zwiększenia udziału obywateli w procesie wybierania, funkcjonowania i kontrolowania niektórych organów publicznych (Dz.U. 2018 poz. 130).

4. Ustawa z dnia 31 marca 2020 r. o zmianie ustawy o szczególnych rozwiązaniach związanych z zapobieganiem, przeciwdziałaniem i zwalczaniem COVID-19, innych chorób zakaźnych oraz wywołanych nimi sytuacji kryzysowych oraz niektórych innych ustaw (Dz.U. 2020 poz. 568).

5. Ustawa z dnia 6 kwietnia 2020 r. o szczególnych zasadach przeprowadzania wyborów powszechnych na Prezydenta Rzeczypospolitej Polskiej zarządzonych w 2020 r. (Dz.U. 2020 poz. 827).

\section{Orzecznictwo}

1. Wyrok Trybunału Konstytucyjnego z 20 lipca 2011 roku, sygn.. K 9/11.

2. Wyrok Trybunału Konstytucyjnego z 3 listopada 2006 roku, sygn. akt K 31/06.

\section{Źródła internetowe}

1. https://koronawirus-w-polsce.pl/ (dostęp 18 marca 2021 roku).

2. https://www.poczta-polska.pl/glosowanie-korespondencyjne-w-kraju/ (dostęp 14 kwietnia 2021 roku).

3. https://prawo.gazetaprawna.pl/artykuly/1472940,wykladowcy-prawa-apel-wybory-prezydenckie-konstytucja-glosowanie-korespondencyjne.html (dostęp 20 kwietnia 2020 roku). 
4. https://pkw.gov.pl/aktualnosci/wyjasnienia-stanowiska-komunikaty/komunikat-panstwowej-komisji-wyborczej-z-dnia-7-maja-2020-roku (dostęp 20 kwietnia 2020 roku).

5. Opinia prawna na temat poselskiego projektu ustawy o zmianie ustawy - Kodeks wyborczy oraz niektórych innych ustaw (druk nr 1786) (http://orka.sejm.gov.pl/rexdomk7.nsf/Opdodr?OpenPage\&nr=1786 (dostęp: 18 marca 2021 roku).

6. Opinia w przedmiocie ustawy z dnia 6 kwietnia 2020 r. o szczególnych zasadach przeprowadzania wyborów powszechnych na Prezydenta Rzeczypospolitej Polskiej zarządzonych w 2020 r. (druk senacki nr 99) http://www.sn.pl/aktualnosci/SitePages/Wydarzenia.aspx?ItemSI$\mathrm{D}=630-0$ dc69815-3ade-42fa-bbb8-549c3c6969c5\&ListName=Wydarzenia (dostęp: 11 marca 2021 roku).

7. Kodeks Dobrej Praktyki w Sprawach Wyborczych, https://bisnetus.files.wordpress.com/2016/03/ kodeks_dobrej_praktyki_w_sprawach_wyborczych.pdf (dostęp 12 kwietnia 2021 roku). 